\title{
Open Letter to Ben Santer
}

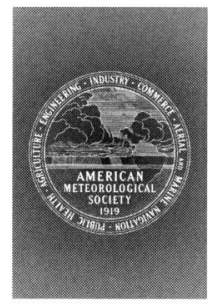

[Editor's Note: The following letter and attachments are being published jointly by the American Meteorological Society and the University Corporation for Atmospheric Research. The position of the Society on the scientific understanding of climate change is provided in the policy statement published in the Bulletin in 1991 (January 1991, p. 57). This policy statement is currently under review.]

25 July 1996

Dr. Benjamin D. Santer

PCMDI, Lawrence Livermore National Laboratory

P.O. Box 808, Mail Stop L-264

Livermore, CA 94550

\section{Dear Ben:}

On behalf of the Executive Committee of the American Meteorological Society and the Trustees of the University Corporation for Atmospheric Research (UCAR), we take this opportunity to support you and the other scientists who have participated in the preparation of the recent IPCC report Climate Change 1995-The Science of Climate Change. We are aware of the tremendous effort you and other climate scientists from many countries around the world have put into this document, and the thought, care, and objectivity which have characterized the process throughout.

We believe that attacks on the IPCC process in general, and you in particular, such as occurred in the editorial-page piece in The Wall Street Journal by Frederick Seitz (attachment 1), have no place in the scientific debate about issues related to global change. Dr. Seitz is a prominent scientist, but his expertise is not atmospheric sciences and he was not involved in the IPCC process. The Wall Street Journal essay is especially disturbing because it steps over the boundary from disagreeing with the science to

(C)1996 American Meteorological Society attacking the honesty and integrity of a particular scientist, namely yourself.

There appears to be a concerted and systematic effort by some individuals to undermine and discredit the scientific process that has led many scientists working on understanding climate to conclude that there is a very real possibility that humans are modifying Earth's climate on a global scale. Rather than carrying out a legitimate scientific debate through the peer-reviewed literature, they are waging in the public media a vocal campaign against scientific results with which they disagree.

We believe that it is important to separate two issues. The first one is the scientific question of how and why climate changes. The second question is, if the climate is changing and humans are causing part of this change, then what should societies do about it. The appropriate arena for debating the first, scientific question is through peer-reviewed scientific publications-not the media. However, the appropriate arenas for debating the second question of public policy are the media and political fora, because answering the second question is inherently a public and political process. And it is the responsibility of the scientific community to participate in the public and policy processes as well as in the scientific process.

The recent exchange in The Wall Street Journal is an example of why attempting to carry out a scientific debate in the media is inappropriate. In response to the Seitz opinion piece, you and 40 other scientists prepared a careful, thoughtful response, which is reprinted in its entirety below (attachment 2). This letter was printed in The Wall Street Journal with minor changes, but without the names of the 40 distinguished 
scientists who supported your rebuttal, including the other three lead co-authors of chapter 8 .

More significantly, a letter supporting you (attachment 3) from Dr. Bert Bolin, Chairman of the IPCC, and Co-chairs of IPCC Working Group I Drs. John Houghton from the United Kingdom and Luiz Gylvan Meira Filho from Brazil which strongly supported your letter was edited so severely that less than half of the original letter was published. Eliminated from the original version was the crucial part explaining the IPCC review process (which was the stated basis for the Seitz attack) and the key, reviewed and agreed-upon conclusion "our ability to quantify the human influence on global climate is currently limited ... nevertheless, the balance of evidence suggests that there is a discernible human influence on global climate."

This example illustrates why essays based upon opinion and other communications in the media or other forms of popular public debate are inappropriate mechanisms for legitimate scientific debate. Letters and opinion pieces can be written by any individual, and one opinion piece can carry as much or more weight in the public's mind as a letter signed by 40 scientists who have passed scientific muster over many years by publishing on the topic in the peerreviewed literature. By necessity, letters and opinion pieces in the public media must be short, simple, and non-technical, and supporting scientific data or theories cannot be provided. Contributions to the public media are not reviewed by scientific experts and can make assertions and statements that are totally without scientific foundation. And finally, key parts may be edited or removed altogether, leading to the possibility that serious changes to the meaning of the contribution may be introduced.

The larger debate related to what actions should be taken by the nation and the world in response to global change will take place in the public and political fora; and it is our responsibility as scientists to take an appropriate role in that larger debate, as you and others have done. What is important scientific information and how it is interpreted in the policy debates is an important part of our jobs. We appreciate your efforts in this respect as well. That is, after all, the very reason for the mix of science and policy in the IPCC.

In summary, we restate our strong support for the integrity and openness of the IPCC process and for you and the many other scientists of diverse views who have participated objectively and in good faith in providing this valuable assessment of the state of our knowledge about climate change.

Sincerely,

Dr. Susan K. Avery

Chairwoman

UCAR Board of Trustees

Dr. Paul D. Try

President

American Meteorological Society

Dr. Richard A. Anthes

President

University Corporation for Atmospheric Research

Dr. Richard E. Hallgren

Executive Director

American Meteorological Society

Attachments as noted in text of letter

cc: Dr. Frederick Seitz

\section{Attachment 1}

Reprinted with permission of The Wall Street Journal copyright 1996

Dow Jones \& Company, Inc. All rights reserved

\section{A Major Deception on 'Global Warming' \\ By Frederick Seitz}

Last week the Intergovernmental Panel on Climate Change, a United Nations organization regarded by many as the best source of scientific information about the human impact on the earth's climate, released "The Science of Climate Change 1995," its first new report in five years. The report will surely be hailed as the latest and most authoritative statement on global warming. Policy makers and the press around the world will likely view the report as the basis for critical decisions on energy policy that would have an enormous impact on U.S. oil and gas prices and on the international economy.

This IPCC report, like all others, is held in such high regard largely because it has been peer-reviewed. 
That is, it has been read, discussed, modified and approved by an international body of experts. These scientists have laid their reputations on the line. But this report is not what it appears to be-it is not the version that was approved by the contributing scientists listed on the title page. In my more than 60 years as a member of the American scientific community, including service as president of both the National Academy of Sciences and the American Physical Society, I have never witnessed a more disturbing corruption of the peer-review process than the events that led to this IPCC report.

A comparison between the report approved by the contributing scientists and the published version reveals that key changes were made after the scientists had met and accepted what they thought was the final peer-reviewed version. The scientists were assuming that the IPCC would obey the IPCC Rules - a body of regulations that is supposed to govern the panel's actions. Nothing in the IPCC Rules permits anyone to change a scientific report after it has been accepted by the panel of scientific contributors and the full IPCC.

The participating scientists accepted "The Science of Climate Change" in Madrid last November; the full IPCC accepted it the following month in Rome. But more than 15 sections in Chapter 8 of the report-the key chapter setting out the scientific evidence for and against a human influence over climate-were changed or deleted after the scientists charged with examining this question had accepted the supposedly final text.

Few of these changes were merely cosmetic; nearly all worked to remove hints of the skepticism with which many scientists regard claims that human activities are having a major impact on climate in general and on global warming in particular.

The following passages are examples of those included in the approved report but deleted from the supposedly peer-reviewed published version:

- "None of the studies cited above has shown clear evidence that we can attribute the observed [climate] changes to the specific cause of increases in greenhouse gases."

- "No study to date has positively attributed all or part [of the climate change observed to date] to anthropogenic [man-made] causes."

- "Any claims of positive detection of significant climate change are likely to remain controversial until uncertainties in the total natural variability of the climate system are reduced."
The reviewing scientists used this original language to keep themselves and the IPCC honest. I am in no position to know who made the major changes in Chapter 8; but the report's lead author, Benjamin D. Santer, must presumably take the major responsibility. IPCC reports are often called the "consensus" view. If they lead to carbon taxes and restraints on economic growth, they will have a major and almost certainly destructive impact on the economies of the world. Whatever the intent was of those who made these significant changes, their effect is to deceive policy makers and the public into believing that the scientific evidence shows human activities are causing global warming.

If the IPCC is incapable of following its most basic procedures, it would be best to abandon the entire IPCC process, or at least that part that is concerned with the scientific evidence on climate change, and look for more reliable sources of advice to governments on this important question.

Mr. Seitz is president emeritus of Rockefeller University and chairman of the George C. Marshall Institute.

\section{Attachment 2}

Original letter sent to The Wall Street Journal by B. Santer and 40 other scientists. Deletions and additions made by The Wall Street Journal editor prior to publication on June 25, 1996 indicated by strikethroughs and italics respectively.

Frederick Seitz's op-ed of June 12 editorial-page piece, "A Major Deception on "Global Warming'" wrongly accuses both the Intergovernmental Panel on Climate Change (IPCC) and a member of the climate science community of violation of procedure and deception. Not only does he thereby demonstrate ignorance of both the topic and the IPCC process, but his actions reflect an apparent attempt to divert attention away from the scientific evidence of a human effect on global climate by attacking the scientists concerned with investigating that issue.

Dr. Seitz discusses editorial changes made to Chapter 8 of the 1995 IPCC report on the science of climate change. The chapter in question evaluates the scientific evidence from many studies that have attempted to detect "unusual" change in the Eearth's climate, and determine whether some portion of that change is due to human activities. Dr. Seitz claims that the alterations made to Chapter 8 , after a November 
1995 IPCC meeting held in Madrid, were in violation of IPCC rules of procedure, and that their effect is to "deceive policy makers and the public into believing that the scientific evidence shows human activities are causing global warming". Similar claims of procedural improprieties have been made by the Global Climate Coalition (GCC), a consortium of industry interests. These claims conjure visions of sinister conspiracies that are entirely unfounded.

All IPCC procedural rules were followed in producing the final, now published, version of the Chapter 8 . The changes made after the Madrid PCC meeting in November 1995 were in response to written review comments received in October and November 1995 from governments, individual scientists, and non-governmental organizations. They were also in response to eomments made by governments and non= governmental organizations during plenary sessions of the Madrid meeting. IPCC procedures required changes in response to these comments, in order to produce the best-possible and most clearly-explained assessment of the science.

There has been no dishonesty, no corruption of the peer-review process and no bias-political, environmental or otherwise. Mr. Seitz claims that the scientific content of Chapter 8 was altered by the changes made to it after the Madrid IPCC meeting. This is incorrect. The present version of Chapter 8, in its Executive Summary, draws precisely the same "bottom-line" conclusion as the original Oct. 9th version of the chapter- "Taken together, these results point towards a human influence on climate". A statement conveying the same message was endorsed unanimously by the governments of the 96 IPCC countries represented at the Madrid meeting.

The pre- and post-Madrid versions of the chapter are equally cautious in their statements. Uncertainties have not been suppressed. Roughly $20 \%$ of Chapter 8 is devoted to the discussion of uncertainties in estimates of natural climate variability and the expected "signal" due to human activities.

The deletions quoted by Seitz relate to the difficulties involved in attributing climate change to the specific cause of human activities, and to uncertainties in estimates of natural climate variability. These issues are dealt with at great length in the published chapter. The basic content of these particular sentences has not been deleted.

Dr. Seitz is not a climate scientist. He was not involved in the process of putting together the 1995 IPCC report on the science of climate change. He did not attend the Madrid IPCC meeting on which he re- ports. He was not privy to the hundreds of review comments received by Chapter 8 Lead Authors. Most seriously, before writing his editorial, he did not contact any of the Lead Authors of Chapter 8 in order to obtain information as to how or why changes were made to Chapter 8 after Madrid. He also did noteontaet eitherProf. Bert Bolin, the Chairman of the IPCC, or those in eharge of the report, the $\mathrm{Co}$-Chairmen of IPCC Working Group I, Sir John Houghton and Dr. Ł.G. Meira Fitho, in order to determine whether IPCE rutes of proeedure had been violated by the ehanges made to Chapter 8 .

Seientists examine all items of evidenee before drawing conetusions. They generally avoid making pronouneements outside their own areas of expertise. Seitz has faited on both eounts, and his conetusions are ineorreet. We urge readers of the Wall Street Journal to read the IPCC report ("Climate Change 1995: The Science of Climate Change", Cambridge University Press, 1996). They will see for themselves that, as required by and stated in IPCC procedural rules, the detection chapter is a "comprehensive, objective and balanced" review of the science.

\section{Benjamin D. Santer \\ Convening Lead Author, Chapter 8 \\ Lawrence Livermore National Laboratory}

Ben Santer (Convening Lead Author, Chapter 8), tawrenee tivermore National Laboratory, U.S.A., Fom Wigley (tead Author, Chapter 8), Nationaleenter for Atmospherie Researeh, U.S.A., Tim Barnett (tead Author, Chapter 8), Seripps Institution of Oeeanography, U.S.A.; Ebby Anyamba (tead Author, Ehapter 8), Goddard Spaee Flight Eenter, U.S.A., Kevin Trenberth (Convening Lead Author, Chapter 4) and Jerry Meeht (Lead Author, Chapter 6), bothat National Center for Atmospherie Researeh, U.S.A., Alan Roboek (Contributor, Chapter 8), University of Maryland, U.S.A., RonStouffer (tead Author, Chap= ter6) and V. Ramaswamy (tead Author, Chapter 2), bothat Geophysieal Fluid Dymamies Laboratory, U.S.A., Miehael Prather (Comvening Lead Author, Ehapter 2), University of California-Irvine, U.S.A., Robert Diekinson (Comvening Lead Author, Chapter 4), University of Arizoma, U.S.A., Mike MaeCracken (Contributor, Chapter 8), Direetor, Office of U.S. Global Change Researeh Program, U.S.A., Don Wuebbles (tead Author, Chapter 2), University of Whinois, U.S.A., Fom Karl (Lead Author, Chapter 3), National Climatie Đata Center, U.S.A., Karl Taylor 
(Comtributor, Chapter 8), Lawrenee Livermore National Laboratory, U.S.A., Peter Bloomfield (Con= tributor, Chapter 8), Merrill Lyneh, U.S.A.; David Randall (Lead Author, Chapter 4), Colorado State University; Andrew Weaver (Lead Author, Chapter 5), University of Vietoria, Canada, Ken Denman (Convening Lead Author, Chapter 10), Instittte of Oeean Seienees, Canada, Franeis Zwiers (Contribu= tor, Chapter 8); Jonathan Gregory, Tim Johns, Kathy Maskell, James Murphy, Simon Fett and Cath Senior (Contributors, Chapter 8); allat Hadley Centre, U.K., John Mitehell (Lead Author, Chapter 6), Hadley Cen= tre, U.K., Phil Jones (Contributor, Chapter 8), Elimatie Researeh Unit, U.K., Riehard Warriek (Con= vening Lead Author, Chapter 7), University of Waikato, New Zealand, Bryant MeAvaney (Lead Author, Chapter 5), Neville Nieholls (Convening Lead Author, Chapter 3) and Seott Power (Contributor, Ehapter 8), all at Bureau of Meteorology Researeh Eentre, Australia, Pavid Karoly (Comtributor, Chapter 8), Monash University, Atnstralia, Jan Enting (Lead Author, Chapter 2) and Paut Fraser (Lead Author, Ehapter 2); both at CSIRO Division of Atmospherie Researeh, Australia, Arie Kattenberg (Comvening tead Author, Chapter 6), Royal Netherlands Meteorologieal Institute, Netherlands; Martin Heimann (Lead Author, Chapter 2) and GabiHegert (Contribu= tor, Chapter 8), Max-Planek Institute for Meteorology, Germany; Dominique Raynaud (Lead Author, Chapter 2), CNRS Laboratoire de Glaciologie, Franee; Jean Jouzel (Lead Author, Chapter 3), Laboratoire de Modelisation du Climate et de l'Environment, Franee.

\section{Attachment 3}

Original letter sent to The Wall Street Journal by B. Bolin, J. Houghton, and L. Filho. Deletions and additions made by The Wall Street Journal editor prior to publication on June 25, 1996 indicated by strikethroughs and italics, respectively.

The Editor

Wall Street Journal

New York

Dear Sir,

Frederiek Seitz's articte 'A major deeeption on 'Global Warming' (WSJ, 12 June 1996) is eompletely without foundation. It makes serious allegations about the Intergovernmental Panel on Climate Change (IPCC) and about the seientists who have eontributed to its work whieh have no basis in faet. Mr. Seitz does not state the souree of his material, and we note for the reeord that he did not eheek his faets either with the HCC offieers or with any of the secientists involved.

The ertueial error in Mr. Seltz's artiele = which eould have been avoided if he had simply taken the time to familiarize himself with IPCC rutes of procedure= is his assumption that the version of the IPCC report from which he quotes was the final version approved by the seientifie authors andaeepted by the HPCE. This is not the ease. He quotes from the draft version of Oetober 1995, which was sent out to detegates in preparation for the November 1995 Plenary Meeting which was held in Madrid. The final version is the one whieh was modiffied in aeeordanee withthe guidance reecived at the Madrid meeting and which has now been published. His attack on Dr. Santer and the other seientists involved is therefore eompletely unfornded.

In the weeks before the Madrid meeting, many ad= ditional review eomments on the Oetober draft were reeeived. For instance, the United States government in stbmitting their points for review, commented on "several ineonsisteneies" and stated "it is essential that the ehapters not be finalized prior to the eompletion of the disetrssions at the IPCC Plenary in Madrid, and that the chapter authors be prevailed upon to modify their text in an appropriate manner following diseus= sion in Madrid."

A stbstantial part of the Madrid meeting was devoted to seientifie presentation and disetussion regarding the extent to which anthropogenie elimate ehange has been deteeted in elimate observations. Further review eomments from experts and government delegates were re= eeived and the Lead Authors were formally asked to eonsider modifieations for improvement. The Plenary meeting finally 'aecepted' Chapter 8 (the ehapter Mr. Seitz attaeks) and the other ten ehapters of the re= port, subjeet to the Lead Authors revising them in the tight of the Madrid disetrssions. The Plenary meeting was, in faet, the final part of the very eomprehensive and throrough IPCC process of peer review.

In accordance with IPCC Procedures, the subsequent changes to the draft of Chapter 8 were under the full scientific control of its convening Lead Author, Đr. Benjamin Santer. No one could have been more thorough and honest in undertaking that task. As the responsible officers of the IPCC, we are com- 
pletely satisfied that the changes incorporated in the revised version were made with the sole purpose of producing the best possible and most clearly explained assessment of the science and were not in any way motivated by any political or other considerations.

It is, of course, easy to take isolated sentences from the earlier version which that have been deleted or replaced to bolster arguments or suspicions such as those presented by Mr. Dr. Seitz. But that is to misunderstand the nature of the science with which we are dealing and the very open IPCC scientific assessment process.

We invite Mr. Seitz and those eoneerned about the integrity of the seience to read the chapter in the IPCC report and also the approved Summary for Poliey Makers (SPM) partieularly as they eoneern the detee= tion issue. Both have been earefully and honestly erafted to explain our understanding of the uneertain= ties and to express etearly the seientifie basis for the eonelusions stated in the SPM (approved by all the delegates at Madrid), namely that "our ability to quantify the human influenee on global elimate is eurrently timited ........ nevertheless, the balanee of evidence suggests that there is a diseernible human influence on global elimate'.

Bert Bolin

Chairman Intergovernmental Panel on Climate Change (IPCC)

John Houghton

Co-Chairman Working Group I, IPCC

Luiz Gylvan Meira Filho

Co-Chairman Working Group I IPCC

Hadley Centre, London Road

Bracknell, United Kingdom

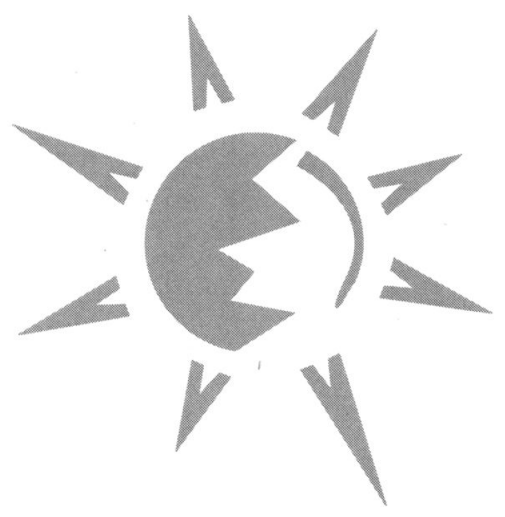

